\title{
Unsustainable exploitation of freshwater wetland turtles and tortoises in central Niger Delta
}

\section{Elijah Ige Ohimain*, Dimie Otobotekere, Biriduba Woyengitonyokopa}

Biodiversity Conservation and Research Group, Biological Science Department, Faculty of Science, Niger Delta University, Amassoma, Nigeria

\author{
Email address: \\ eohimain@yahoo.com (E. I. Ohimain)
}

\section{To cite this article:}

Elijah Ige Ohimain, Dimie Otobotekere, Biriduba Woyengitonyokopa. Unsustainable Exploitation of Freshwater Wetland Turtles and Tortoises in Central Niger Delta. International Journal of Environmental Monitoring and Analysis. Vol. 2, No. 2, 2014 , pp. 57-64. doi: $10.11648 /$ j.ijema.20140202.11

\begin{abstract}
Wildlife is commonly exploited as sources of animal protein in Nigeria. This study was designed to assess the rate of wildlife exploitation in 2 communities in Delta State, Nigeria specialized in the sale of turtles and tortoises. These two communities receive 1,512 turtles and tortoises weekly from hunters and display them for sales along the East-West Road. Fortnightly field surveys in these communities show that 12 shops displayed $144-212$ numbers of turtles and tortoises while the rest are kept in bulk storage. Each shop sells $16-20$ (average 18) on favorable business days and $3-9$ (average 6) on unfavorable days. The retailer makes an average profit of N1000, N 3,500 and N 4000 per unit of small, medium and large species respectively (US $\$ 1=\mathrm{N} 156$ ). The numbers of retailers are increasing. The turtles and tortoises were captured from freshwater wetlands located in an island bounded in the north by the bifurcation of River Niger at Aboh, and between Ramos River to the west and San Bartholomew River to the east and in the south by the mangrove ecosystem at the fringe of the Atlantic Ocean. These wetlands turtles and tortoises are mostly exploited for meat, traditional medicine and as source of employment and income. The species exploited include 2 species of turtles (Pelusios niger and $P$. castaneus) and tortoises (Kinixys erosa and K. homeana). The study concluded that this pattern of wildlife exploitation is unsustainable.
\end{abstract}

Keywords: Biodiversity, Conservation, Herpetofauna, Wetlands

\section{Introduction}

Nigeria is blessed with abundant wetlands, which covers $28,000 \mathrm{~km}^{2}$ i.e. about $3 \%$ of the $923,770 \mathrm{~km}^{2}$ total surface area of the country [1]. Most of the Nigerian wetlands are located in the Niger Delta covering about $20,000 \mathrm{~km}^{2}$ [2], thus accounting for $71.4 \%$ of the total wetlands in the country. Nigeria has 11 Ramsar designated wetland sites covering about $10,700 \mathrm{~km}^{2}$ but only about $5 \%$ of these Ramsar sites are located in the Niger Delta [3]. The Niger Delta wetlands consist of freshwater $\left(10,000 \mathrm{~km}^{2}\right)$ and mangrove wetlands separated by transition wetlands dominated by Pandanus sp., Dalburger escatophylum and Machaerum lunatus. A relatively narrow strip of beach ridges/barrier islands separate the mangroves from the Atlantic Ocean. Nigeria also has the largest area of mangroves in Africa and the third largest in the world covering $11,134 \mathrm{~km}^{2}$ [4]. Over $70 \%$ of Nigeria's mangroves are located in the Niger Delta region, which have been listed in the UNESCO's "Tentative List" of Potential World Heritage Sites [5]. Nigerian mangroves consists of 3 species of Rhiziphora, Rhizophora racemosa (tall red mangrove), Rhizophora mangle (short red mangrove) and Rhizophora harrisonii (short red mangrove) and one species of white mangrove, Avicennia germinans and black mangrove, Laguncularia racemosa. Rainfall is high $(2,500$ $-3,500 \mathrm{~mm}$ per annum) and occurs virtually all year round in the region, humidity is also high exceeding $80 \%$, while temperature is in the order of $28-33^{\circ} \mathrm{C}$.

Being part of the Guinean forest, the Niger Delta have been ranked 12th among the World's 25 biodiversity conservation hotspots [6] because about $60-80 \%$ of all plants and animal found in Nigeria are present with many endemic to the Niger Delta region. The Niger Delta is also listed among the World's 871 ecoregions [7]. The Niger Delta contains a rich assemblage of wildlife $[8,9]$ including mammals, birds, amphibians, reptiles, fishes, and insects. The Niger Delta is home to nearly all of Nigeria's endemic 
or near-endemic mammals comprise 6 IUCN Red List mammals including the forest elephant (Loxodonta africana), the West African manatee (Trichechus senegalensis), the Nigerian White-throated guenon (Cercopithecus erythrogaster pococki), the Sclater's guenon (Cercopithecus sclateri), the pygmy hippopotamus (Choeropsis liberiensis heslopi) and the Niger Delta red colobus monkey (Procolobus epieni). Five species of endangered species of sea turtle visit the beaches of the Niger Delta at Akassa beach and probably breed there: the leatherback (Dermochelys coriacea), green (Chelonia mydas) and olive ridley (Lepidochelys olivacea), loggerhead (Caretta caretta), and the critically endangered hawksbill (Eretmochelys imbricata) [5, 10]. About 148 water-related bird species from 38 families including 5 species of global conservation interest have been found in the Niger Delta. About 30 species of amphibians have been identified in the Niger Delta. Also, the fish species is highly diverse including 313 indigenous species belonging to 158 genera, 64 families out of which 20 species are endemic [5]. A list of selected wildlife species of conservation importance are presented in Table 1.

Table 1. Selected wildlife of conservation importance.

\begin{tabular}{|c|c|c|c|}
\hline & $\begin{array}{l}\text { Common } \\
\text { names }\end{array}$ & Scientific names & $\begin{array}{l}\text { conservation } \\
\text { status }\end{array}$ \\
\hline \multirow{25}{*}{ Mammalia } & Red river hog & Potamochoerus & \multirow{4}{*}{$\mathrm{EN}^{*}, \mathrm{E}^{* *}$} \\
\hline & (Bush Pig) & porcus & \\
\hline & White-throated & Cercopithecus & \\
\hline & Guenon & erythrogaster & \\
\hline & Sclater's & Cercopithecus & \multirow{2}{*}{$\mathrm{EN}^{*}, \mathrm{E}^{* *}$} \\
\hline & Guenon & Sclateri & \\
\hline & $\begin{array}{l}\text { African } \\
\text { Elephant }\end{array}$ & Loxodonta africana & $\mathrm{NT}^{*}, \mathrm{E}^{* *}$ \\
\hline & $\begin{array}{l}\text { African } \\
\text { manatee }\end{array}$ & Tricheus senegalansis & $\mathrm{VU}^{*}, \mathrm{E}^{* *}$ \\
\hline & Sitatunga & Tragelaphus spekei & $\mathrm{E}^{* *}$ \\
\hline & $\begin{array}{l}\text { Water } \\
\text { chevrotain }\end{array}$ & $\begin{array}{l}\text { Hyemoschus } \\
\text { aquaticus }\end{array}$ & \multirow[t]{6}{*}{$\mathrm{E}^{* *}$} \\
\hline & Red-legged & Heliosciurus & \\
\hline & squirrel & rufobranchium & \\
\hline & Mona monkey & Cercopithecus mona & \\
\hline & Putty-nosed & Cercopithecus & \\
\hline & Monkey & nictitans & \\
\hline & $\begin{array}{l}\text { Maxwell's } \\
\text { duiker }\end{array}$ & $\begin{array}{l}\text { Cephalophus } \\
\text { maxwelli }\end{array}$ & $\mathrm{LR} / \mathrm{nt}^{*}$ \\
\hline & $\begin{array}{l}\text { Red-capped } \\
\text { mangabey }\end{array}$ & Cercocebus torquatus & $\mathrm{LR} / \mathrm{nt}^{*}$ \\
\hline & $\begin{array}{l}\text { Brush-tailed } \\
\text { porcupine }\end{array}$ & Atherurus africanus) & $\mathrm{E}^{* *}$ \\
\hline & Tree pangolin & Phalaginus trocuspis & $\mathrm{E}^{* *}$ \\
\hline & $\begin{array}{l}\text { Long-tailed } \\
\text { pangolin }\end{array}$ & $\begin{array}{l}\text { Uromanis } \\
\text { tetradactyle }\end{array}$ & \multirow[t]{2}{*}{$\mathrm{E}^{* *}$} \\
\hline & $\begin{array}{l}\text { Two-spotted } \\
\text { Palm Civet }\end{array}$ & Nandinia binotata & \\
\hline & Crested Genet & Genetta cristata & \multirow[t]{3}{*}{$\mathrm{E}^{* *}$} \\
\hline & Cape Clawless & Aonyx capensis & \\
\hline & $\begin{array}{l}\text { Otter } \\
\text { Snot-necked }\end{array}$ & & \\
\hline & $\begin{array}{l}\text { Spot-necked } \\
\text { otter }\end{array}$ & Lutra maculicollis & \multirow[t]{3}{*}{$\mathrm{VU}^{*}, \mathrm{E}^{* *}$} \\
\hline \multirow{2}{*}{ Aves } & Blue-breasted & Halcyon malimbica & \\
\hline & Intermediate & Egretta intermedia & \\
\hline
\end{tabular}

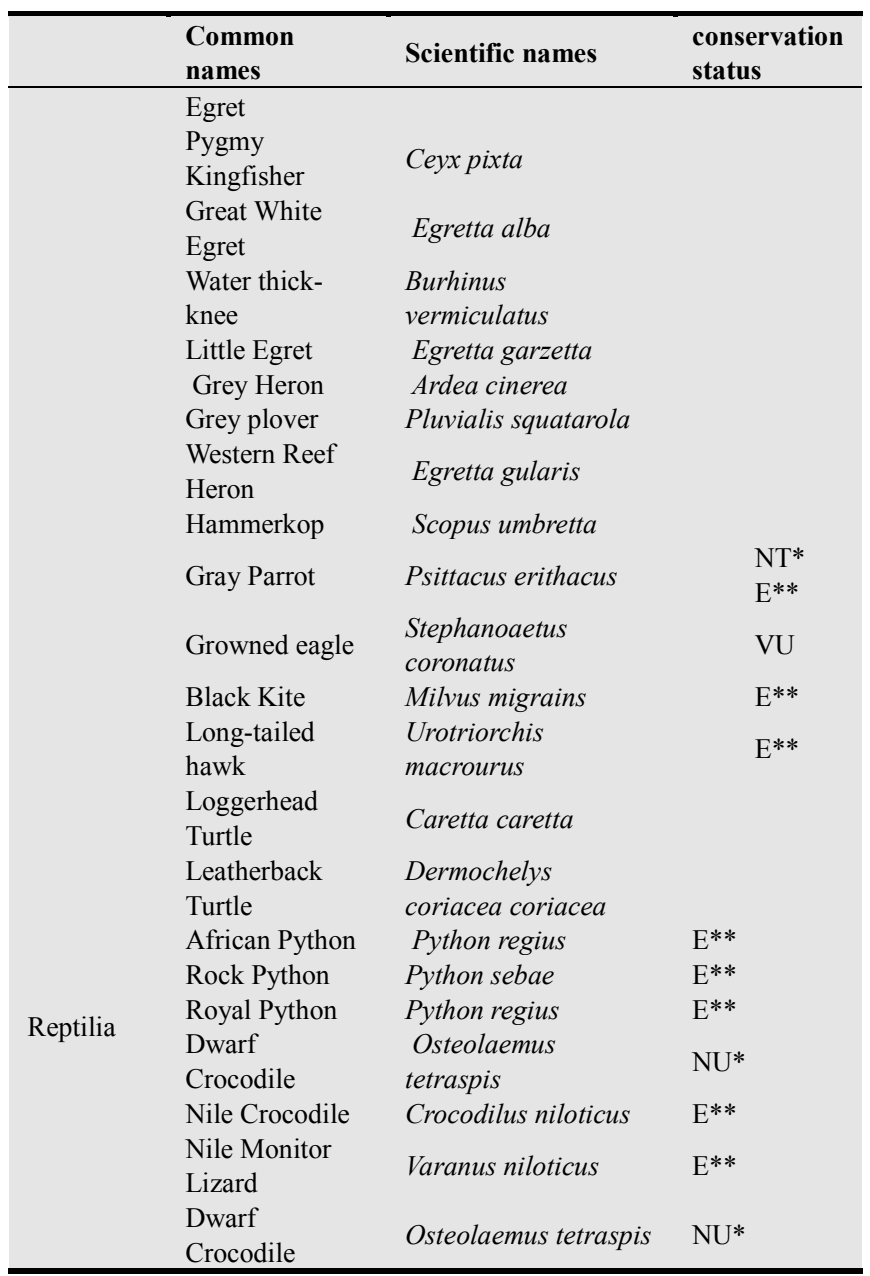

* Listed in IUCN Red List

** Listed in Act \# 11 (1985) endangered species decree of Federal Republic of Nigeria (source: this study).

Both wildlife and their habitats are important components of the ecosystem. Turtles and tortoises are important members of the global food chain. They are particularly important in the dispersal of seeds [11]. Turtles and tortoises play significant roles in the ecosystem. According to Dreslik et al [12], because turtles are relatively long-lived, they comprise a large portion of the total biomass in a community, locking nutrients longer than most organisms. Though, the structure of turtle assemblages are poorly understood [13], studies have found that freshwater turtle assemblages structure changes across habitats, resources and seasonal gradients [12, 14-16]. But changes in wetlands and wildlife generally and turtles/tortoises in particular are not natural but due to anthropogenic forces. Several factors combine to destroy wetlands and wildlife in the Niger Delta including solid waste disposal [17, 18], oil and gas exploration [2, 19], dredging, sandfilling and reclamation (20-22, 23], urbanization, wood logging and exploitation of forest products $[3,24]$ and recently, natural disaster particularly flooding [25]. Onojeghuo and Blackburn [26] reported that the fragile mosaic of aquatic, wetland and terrestrial ecosystems in the Niger Delta region is challenged by a 
diverse range of environmental problems resulting from agricultural land degradation, changes in local hydrology resulting from sea level rise, pollution from oil industry activities such as pipeline construction, oil spills, seismic exploration, dredging, drilling, over-exploitation of forest resources for food and illegal felling of trees. Biodiversity loss is not restricted to Nigeria, but it is has now reached a global scale [6, 27, 28].

Globally, freshwater turtles and tortoises are threatened with about $40 \%$ of the 300 extant taxa are regarded as vulnerable or endangered, and may face extinction if appropriate conservation measures are not implemented [29]. Species most vulnerable to extinction are those having small population, and therefore tiny relict distributions, which makes them difficult to survey and therefore easily missed [30]. Factors that have caused widespread declines in the abundance and distribution of turtle and tortoises include habitat destruction, pollution and over-exploitation for trade in meat, pets and traditional medicines [30-32]. The annual practice of bush burning especially during the dry seasons is also responsible for the decline in turtles and tortoises. Other factors that have been reported to cause the decline of these herpetofauna includes decreasing habitats, restricted range, habitat fragmentation, habitat shifts, predation and unsustainable exploitation [30]. In Nigeria, wildlife is commonly exploited for meat called "bush meat" [33]. About $80 \%$ of the protein intake of many communities is obtained from bush meat [8, 24, 34]. Bush meat is commonly displayed in shops along major highways in Nigeria [33]. Two communities in Delta State, Kolowari and Aven, turtles and tortoises are displayed in almost all the shops for sale. Hence, a team of scientist from the Niger Delta University mobilized to study the pattern of turtle and tortoise exploitation in the freshwater swamp of the Niger Delta. Information from this study would be useful to natural resource conservationist, wetland managers and for the IUCN to refine their information on some of these species that are data deficient or not evaluated.

\section{Materials and Methods}

In the month of July and August 2012, preliminary field trips were undertaken to two communities (Kolowari and Aven in Delta State, Nigeria) where turtles and tortoises are displayed for sale in large scale. The turtles and tortoises were identified according to the identification keys by Ernst and Barbour [36] and sorted and counted at 7 shops in Kolowari and 5 shops in Aven. Sampling was done fortnightly during the preliminary studies, while long-term monitoring was carried monthly from January to December 2013. Measurement of the dimensions of the turtles was done using tape, while the carapace thickness was measured using calipers. Weighing scale was used to measure the weight of the randomly selected turtles. The identified species were subjected to IUCN Red List of Threatened species (2012 version 2) to obtain their conservation status.

The wildlife vendors and hunters were interviewed to obtain the following information; wholesale and retail prices of turtles/tortoise, the number of species sold daily, frequency of bulk supply from hunters and the ultimate uses of purchased species. Hunters were further interviewed on the trapping methods and the diversity of traps used. Hunters were also followed to the forest to study the ecosystem from where the species were captured.

\section{Results and Discussion}

The physical counts of turtles and tortoise displayed for sale in the two studied communities are presented in Table 2 .

Table 2. Physical counts of turtle and tortoise displayed for sale (preliminary studies).

\begin{tabular}{|c|c|c|c|c|c|}
\hline Community & Shop \# & \multicolumn{4}{|c|}{ Counts (No.) } \\
\hline & & 16 & 30 & 13 & 27 \\
\hline & & July & July & August & August \\
\hline & & 2012 & 2012 & 2012 & 2012 \\
\hline & 1 & 21 & 13 & 14 & 12 \\
\hline & 2 & 14 & 16 & 12 & 14 \\
\hline Kolowari & 3 & 13 & 15 & 17 & 15 \\
\hline N 05o12'44.8" & 4 & 11 & 16 & 22 & 14 \\
\hline \multirow[t]{5}{*}{ E006o09'52.8” } & 5 & 15 & 18 & 11 & 20 \\
\hline & 6 & 4 & 26 & 16 & 20 \\
\hline & 7 & 24 & 16 & 14 & 15 \\
\hline & $\begin{array}{l}\text { Sub- } \\
\text { Total }\end{array}$ & 102 & 120 & 106 & 110 \\
\hline & 1 & 14 & 31 & 6 & 20 \\
\hline Aven & 2 & 12 & 17 & 5 & 16 \\
\hline N 05o12’06.7" & 3 & 8 & 9 & 4 & 10 \\
\hline \multirow[t]{4}{*}{ E006o09'08.8" } & 4 & 21 & 31 & 6 & 12 \\
\hline & 5 & 13 & 4 & 17 & 14 \\
\hline & $\begin{array}{l}\text { Sub- } \\
\text { Total }\end{array}$ & 68 & 92 & 38 & 72 \\
\hline & TOTAL & 170 & 212 & 144 & 182 \\
\hline
\end{tabular}

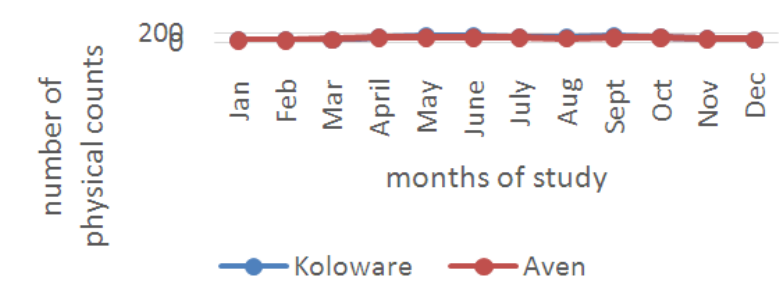

Figure 1. Seasonal pattern of the number of turtle and tortoise displayed for sales during the long term studies (2013).

At each fortnight sampling days, a sub-total of $144-212$ turtle/tortoises were found, which totaled 708 in number for the 4 sampling epochs. In 2013, 123 - 280 numbers of turtle/tortoises were found on each visit (Table 3, Fig. 1), with catches higher during the rainy season (May October). Of this population, the West African black forest turtle, Pelusios niger accounted for $62 \%$, while the West African mud turtle accounted for $36.3 \%$, the Home's 
hinged-back tortoise Kinixys homeaneus accounted for $0.9 \%$ while the serrated hinged-back turtle, Kinixys erosa accounted for the rest $0.8 \%$ (Table 4). Hence, over $98 \%$ are turtles, while $<2 \%$ are tortoises. Luiselli and Akeni [23] have similarly sampled large population (510) of freshwater turtles belonging to four different species (Trionyx triunguis, Pelusios castaneus, Pelusios niger and Pelomedusa subruta) within the drainage area of the Nun River. During a 30 day field work, Politano [35] found 48 Pelusios niger, 31 Pelusios castaneus, 4 Pelomedusa and 2 Trionyx triunguis. Hamadina et al [24] found Pelusios niger and Kinixys erosa in Wilberforce Island within the drainage area of River Nun. Martin [33] reported that turtle/tortoises accounted for about $0.4 \%$ of the wildlife displayed for sale along the highways in southern Nigeria.

Table 3. Physical counts of turtle and tortoise displayed for sales (2013).

\begin{tabular}{|c|c|c|c|c|c|c|c|c|c|c|c|c|c|}
\hline Location & Stores & Jan & Feb & Mar & April & May & June & July & Aug & Sept & Oct & Nov & Dec \\
\hline \multirow{13}{*}{ Koloware } & 1 & 12 & 10 & 12 & 15 & 17 & 16 & 13 & 12 & 16 & 17 & 14 & 10 \\
\hline & 2 & 10 & 9 & 9 & 12 & 10 & 11 & 7 & 9 & 7 & 8 & 9 & 8 \\
\hline & 3 & 7 & 9 & 10 & 14 & 16 & 11 & 14 & 10 & 11 & 13 & 9 & 7 \\
\hline & 4 & 10 & 8 & 10 & 19 & 23 & 22 & 16 & 14 & 21 & 15 & 13 & 11 \\
\hline & 5 & 12 & 10 & 13 & 21 & 26 & 34 & 27 & 26 & 30 & 21 & 15 & 11 \\
\hline & 6 & 10 & 12 & 10 & 15 & 17 & 18 & 20 & 21 & 22 & 12 & 14 & 12 \\
\hline & 7 & 9 & 6 & 8 & 13 & 15 & 10 & 8 & 10 & 14 & 12 & 10 & 7 \\
\hline & 8 & 4 & 1 & 3 & 6 & 8 & 5 & 5 & 8 & 6 & 7 & 4 & 4 \\
\hline & 9 & - & 3 & 2 & 6 & 8 & 4 & 3 & 6 & 4 & 6 & 3 & 2 \\
\hline & 10 & - & - & 2 & 4 & 7 & 5 & 7 & 2 & 7 & 6 & 4 & 4 \\
\hline & 11 & - & - & - & 2 & 5 & 2 & 3 & 2 & 5 & 2 & - & 1 \\
\hline & 12 & - & - & - & - & 5 & 8 & 7 & - & 11 & 4 & 5 & 5 \\
\hline & 13 & - & - & - & - & 2 & 1 & 1 & - & 3 & 1 & - & - \\
\hline \multirow{13}{*}{ Aven } & Sub Total & 74 & 68 & 79 & 127 & 159 & 147 & 131 & 115 & 157 & 124 & 100 & 82 \\
\hline & 1 & 9 & 7 & 10 & 17 & 17 & 19 & 17 & 19 & 17 & 16 & 14 & 10 \\
\hline & 2 & 7 & 9 & 13 & 14 & 16 & 19 & 20 & 15 & 16 & 13 & 10 & 9 \\
\hline & 3 & 12 & 12 & 14 & 17 & 15 & 17 & 14 & 16 & 18 & 19 & 14 & 11 \\
\hline & 4 & 9 & 6 & 8 & 10 & 13 & 15 & 14 & 10 & 9 & 11 & 10 & 8 \\
\hline & 5 & 15 & 11 & 14 & 24 & 22 & 18 & 20 & 19 & 27 & 23 & 20 & 18 \\
\hline & 6 & 9 & 7 & 9 & 10 & 15 & 11 & 9 & 11 & 10 & 13 & 10 & 11 \\
\hline & 7 & 5 & 3 & 6 & 8 & 9 & 8 & 5 & 6 & 9 & 8 & 10 & 7 \\
\hline & 8 & - & - & 2 & 6 & 7 & 5 & 5 & 4 & 5 & 5 & 6 & 4 \\
\hline & 9 & - & - & - & 3 & 4 & 3 & 1 & 1 & 3 & 4 & 2 & 1 \\
\hline & 10 & - & - & - & - & 3 & 1 & 4 & - & 1 & 1 & - & - \\
\hline & Sub Total & 66 & 55 & 76 & 109 & 121 & 116 & 109 & 101 & 115 & 113 & 96 & 79 \\
\hline & Grand total & 140 & 123 & 155 & 236 & 280 & 263 & 240 & 216 & 272 & 237 & 196 & 161 \\
\hline
\end{tabular}

Table 4. Features, habitat description, conservation status of fresh water turtles and tortoises.

\begin{tabular}{|c|c|c|c|c|c|c|}
\hline Common names & Scientific names & $\begin{array}{l}\text { Vernacular name } \\
\text { (Ijaw language) }\end{array}$ & $\begin{array}{l}\text { Percentage } \\
\text { distribution }\end{array}$ & $\begin{array}{l}\text { Feeding } \\
\text { habits }\end{array}$ & IUCN conservation status & $\begin{array}{l}\text { Preferred } \\
\text { habitats }\end{array}$ \\
\hline $\begin{array}{l}\text { West African } \\
\text { black forest turtle }\end{array}$ & $\begin{array}{l}\text { Pelusios niger } \\
\text { (Dumeril \& } \\
\text { Bibron, 1835) }\end{array}$ & Beniwiri & $62.0 \%$ & Omnivorous & Not evaluated & $\begin{array}{l}\text { Freshwater } \\
\text { wetlands, rivers, } \\
\text { permanent water } \\
\text { bodies }\end{array}$ \\
\hline $\begin{array}{l}\text { West African mud } \\
\text { turtle }\end{array}$ & $\begin{array}{l}\text { Pelusios } \\
\text { castaneus } \\
\text { (Schweigger, } \\
\text { 1822) }\end{array}$ & Beniwiri & $36.3 \%$ & Omnivorous & Not evaluated & $\begin{array}{l}\text { Freshwater } \\
\text { wetlands, rivers }\end{array}$ \\
\hline $\begin{array}{l}\text { Home's Hinge- } \\
\text { back tortoise }\end{array}$ & $\begin{array}{l}\text { Kinixys homeana } \\
\text { (Bell, 1827) }\end{array}$ & Ogboiwiri & $0.9 \%$ & Omnivorous & $\begin{array}{l}\text { Vulnerable A2cd ver } 3.1 \\
\text { (i.e. Population trend is } \\
\text { decreasing) }\end{array}$ & $\begin{array}{l}\text { Freshwater } \\
\text { wetlands }\end{array}$ \\
\hline $\begin{array}{l}\text { Serrated Hinge- } \\
\text { back tortoise }\end{array}$ & $\begin{array}{l}\text { Kinixys erosa } \\
\text { (Schweigger, } \\
1822 \text { ) }\end{array}$ & Ogboiwiri & $0.8 \%$ & Omnivorous & $\begin{array}{l}\text { Data deficient ver. } 2.3 \text { (i.e. } \\
\text { need updating) }\end{array}$ & $\begin{array}{l}\text { Freshwater } \\
\text { wetlands }\end{array}$ \\
\hline
\end{tabular}

The Pelusios turtle like in other previous studies are dominant among the herpetofauna of Nun River. The morphometric measurements of the Pelusios turtle found in the study area is presented in Table 5. The males $(2.83 \pm 0.22 \mathrm{~kg})$ were significantly $(\mathrm{P}<0.05)$ heavier than the females $(2.06 \pm 0.19 \mathrm{~kg})$. In other parameters measured, except carapace thickness, the males were significantly bigger than the females (Table 5). Ernst and Barbour [36] reported that $P$. niger has carapace length of $22.5 \mathrm{~cm}$, whereas $P$. castaneus has a carapace length of $24-38 \mathrm{~cm}$, and in both cases the males have longer and thicker tails. $K$. erosa and $K$. homeana have carapace length of $32.2 \mathrm{~cm}$ and $21 \mathrm{~cm}$ respectively.

In terms of feeding habits, our study found that all the 4 
species are omnivorous feeding on fish, water snails, vegetation such as water lettuce, fruits etc. This finding is in agreement to that of Luiselli and Akuni [23] who reported that these freshwater turtles and tortoises are omnivorous, but different from Ernst and Barbour [36] that reported 3 of the species as omnivores, but $\mathrm{P}$. niger as carnivorous. The ecological significance of the feeding habits of these herpetofauna has been reported by authors. The omnivorous habit of freshwater turtles and tortoises are important in the trophic chain [23], as seed dispersants [11] and because of their relatively longevity lock up nutrient into biomass [12].

Table 5. Physical measurements of Pelusios turtles.

\begin{tabular}{lccccc}
\hline & df & Male & Female & $\begin{array}{c}\text { t } \\
\text { value } \\
(\mathbf{2} \\
\text { tailed) }\end{array}$ & p value \\
\hline $\begin{array}{l}\text { Weight } \\
\text { (kg) }\end{array}$ & 22 & $2.833 \pm 0.227$ & $2.058 \pm 0.187$ & 2.633 & $0.015^{*}$ \\
$\begin{array}{l}\text { Carapace } \\
\text { Length }\end{array}$ & 22 & $30.375 \pm 1.625$ & $25.375 \pm 1.155$ & 2.508 & $0.020^{*}$ \\
(cm) & & & & & \\
$\begin{array}{l}\text { Width } \\
\text { (cm) }\end{array}$ & 22 & $26.750 \pm 2.097$ & $23.625 \pm 1.160$ & 3.391 & $0.003^{*}$ \\
$\begin{array}{l}\text { Shell } \\
\text { Thickness } \\
\text { (cm) }\end{array}$ & 22 & $2.967 \pm 0.214$ & $3.033 \pm 0.144$ & -0.259 & $0.798 \mathrm{NS}$ \\
$\begin{array}{l}\text { Head } \\
\text { length } \\
(\mathrm{cm})\end{array}$ & 22 & $9.275 \pm 0.474$ & $7.250 \pm 0.506$ & 2.921 & $0.008^{*}$ \\
$\begin{array}{l}\text { Head } \\
\text { width } \\
\text { (cm) }\end{array}$ & 22 & $7.458 \pm 0.257$ & $5.867 \pm 0.500$ & 2.833 & $0.010^{*}$ \\
\hline
\end{tabular}

* significant, NS = not significant

The conservation status of the species are presented in Table 4 showing that the 2 tortoise species have been evaluated by IUCN while the turtles have not been evaluated (IUCN 2012). While $K$. erosa is data deficient, $K$. homeana has been rated as vulnerable with population trend declining. Nevertheless, all the 4 species are listed in the catalogue of Life database (www.catalogueoflife.org assessed 25 October 2012). Species are listed as data deficient or 'not evaluated' in the IUCN database especially if there are insufficient quantitative data to permit their evaluation. In this study, we present data showing the extent of trapping and selling of these important herpetofauna.

Table 6 shows that on a weekly basis about 882 and 630 turtles/tortoises are captured by the hunters and sold to wildlife vendors in Kolowari and Aven respectively. Typically, the vendors receive 3 bags containing 14 turtles thrice weekly. These turtles/tortoise are displayed upside down (Fig. 2) in shops along the highways until they are sold. The rate for the sale of these species differs depending on size (Table 7). Relatively small sizes are sold for $2,500(\$ 1=\$ 156)$ each, the medium size $\$ 6,500$ and the large size 10,000 . The wildlife vendors make a profit of \# $1000-4000$ per species depending on the size and market season. Generally, each of the 12 sales shops sells $16-20$ (mean 18) on favorable days and 3-9 (mean 6) on unfavorable sale days. Displaying of wildlife species for sale along major highways is a common practice in Nigeria. But these two communities are specialized in the sales of turtle and tortoises. Turtle and tortoises are displayed in these communities all year round irrespective of the seasons. Interviews of hunters and vendors shows that the turtles and tortoises are mostly consumed as bush meat and for traditional medicine and to a lesser extent as pets (Table 8). Some of the vendors sometimes supply herpetofauna in bulk to some hotels in Yenagoa, the capital city of Bayelsa State, Nigeria.

Table 6. Number of turtles and tortoises supplied weekly to the wildlife markets at Kolowari and Aven.

\begin{tabular}{lll}
\hline & $\begin{array}{l}\text { Kolowari (7 } \\
\text { shops) }\end{array}$ & $\begin{array}{l}\text { Aven (5 } \\
\text { shops) }\end{array}$ \\
\hline $\begin{array}{l}\text { Supply frequency per week } \\
\begin{array}{l}\text { No. of bags supplied per trip } \\
\text { Average number of turtles \& tortoises per } \\
\text { bag }\end{array}\end{array}$ & 3 & 3 \\
$\begin{array}{l}\text { Total number supplied per shop } \\
\begin{array}{l}\text { Total number of turtle to all the shops per } \\
\text { week }\end{array}\end{array}$ & 14 & 3 \\
\hline
\end{tabular}

Table 7. Unit prices of turtles and tortoises.

\begin{tabular}{clclll}
\hline Turtle Size & $\begin{array}{l}\text { Wholesale } \\
\text { (purchase } \\
\text { from hunters) }\end{array}$ & $\begin{array}{l}\text { price } \\
\text { price } \\
\text { (N) }\end{array}$ & $\begin{array}{l}\text { Retail price } \\
\text { (A) }\end{array}$ & $\begin{array}{l}\text { Profit } \\
\text { turtle } \\
\text { (N) }\end{array}$ & per \\
\hline Small & 1,500 & & 2,500 & 1,000 \\
Medium & 3,000 & & 6,500 & 3,500 \\
Big & 6,000 & & 10,000 & 4,000 \\
\hline
\end{tabular}
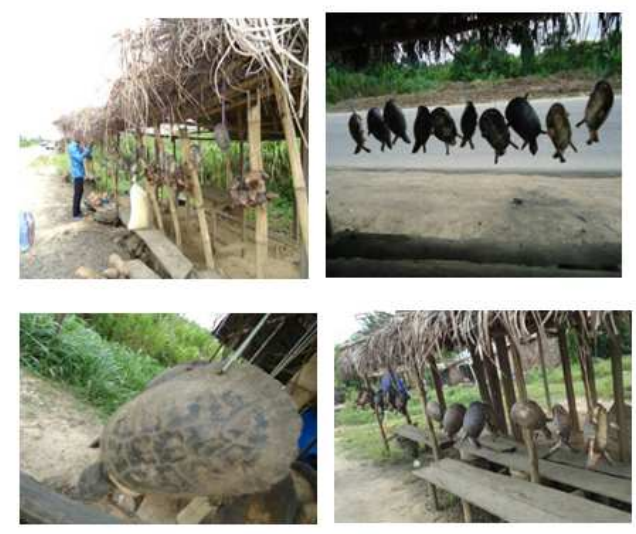

Turtles

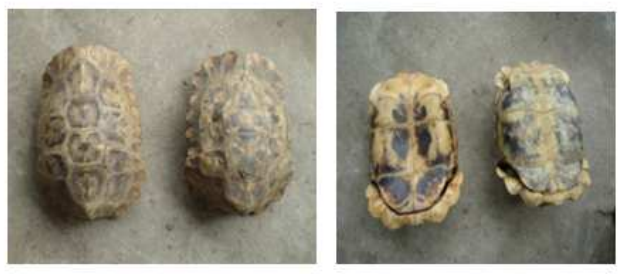

Tortoises

Fig 2. Turtles and tortoises displayed for sale along the East-West road, Central Niger Delta. 
Table 8. Uses of turtles and tortoises.

\begin{tabular}{lll}
\hline Uses & Relative importance & Ranking* \\
\hline Meat & For food & $* * * *$ \\
Medicine & Treatment of ailments & $* * *$ \\
$\begin{array}{l}\text { Source of } \\
\text { income }\end{array}$ & $\begin{array}{l}\text { Generation of income for } \\
\text { hunters and traders }\end{array}$ & $* * * *$ \\
Pets & It is used as pet for homes & $*$ \\
\hline
\end{tabular}

* Relative importance

Hunters used various traps including baited hook, basking and sliding traps (Table 9, Fig. 3). The sliding traps are set across the river course and/or swamp with bait, which will attract the turtles/ tortoises. Some authors have reported similar traps used for turtle and tortoise trapping $[38,39]$. The vegetation is dominated by oil palm, raffia palm, Anthocleista sp, Musanga sp, Mitragyra symphonia and other hard wood, and shrubs (Table 10). This study like many others where these species have been reported was carried out in the wetland area of the central Niger Delta between San Bartholomew River and Ramos River [23, 24, 35]. Powell [8,9] studies were mostly carried out in the freshwater swamp of central Niger Delta, which is within the catchment area of the Nun River. It therefore appears that these species range in the fresh water between Kaiama (East) through Patani, Kolowari and Aven to Bomadi (West). It is therefore uncertain if these species are localized within this region in Nigeria. Though Ernst and Barbour [36] reported that Pelusios niger are confined to West Africa from Ghana to Cameroun; Pelusios castaneus from Senegal to Nigeria; Kinixys erosa from Gambia to Gabon, Congo and Uganda; K. homeanus from Liberia through Ivory Coast (Cote D'Ivore) to Zaire.

Table 9. Types of Traps use for hunting of turtles.

\begin{tabular}{|c|c|c|}
\hline Types & $\begin{array}{c}\text { Vernacular (Ijaw) } \\
\text { names }\end{array}$ & Methods \\
\hline $\begin{array}{l}\text { Baited hook } \\
\text { traps }\end{array}$ & Ikpokpoba & $\begin{array}{l}\text { Bait is attached to a trap that } \\
\text { will attract the turtle and placed } \\
\text { along the river or wetlands. }\end{array}$ \\
\hline $\begin{array}{l}\text { Basking } \\
\text { Traps }\end{array}$ & Egbedeguma & $\begin{array}{l}\text { The basking trap is set in the } \\
\text { river or wetlands to capture } \\
\text { turtles and tortoises }\end{array}$ \\
\hline Sliding trap & Eteu & $\begin{array}{l}\text { Bait is placed inside the trap. } \\
\text { The trap slide to close when a } \\
\text { turtle or tortoise enters }\end{array}$ \\
\hline
\end{tabular}

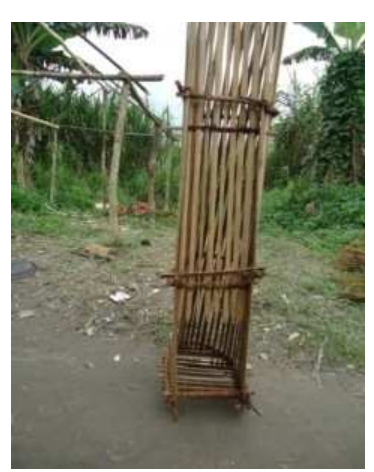

Fig 3. Sliding trap used to capture freshwater turtles and tortoises.
Table 10. Common plant species in the freshwater swamp habitats of turtles and tortoises.

\begin{tabular}{ll}
\hline Scientific name & Local name \\
\hline Alchornea cordifolia & Christmas bush \\
Musanga sp & Umbrella tree/corkwood \\
Chromoleana odorata & Siam weed/malay weed \\
Costus afer & Ginger lily/bush cane \\
Panicum maximum & Grass \\
Elaeis guineensis & Oil palm tree \\
Nephrolepis biserata & Ferns \\
Mitragyna ciliata & Abura \\
Anthocleista vogelii & Cabbage tree \\
Pentachletra macrophylla & Oil bean tree \\
Afromomium sp. & \\
Cyrtosperma senegalensis & Swamp aureum \\
Raphia hookeri & Raffia palm \\
\hline
\end{tabular}

The sustainability of this pattern of natural resource (turtle/tortoises) exploitation is questionable. Evidence from the interview of hunters show that these species are on the decline because hunters now capture less number of turtle/tortoises with more effort and travel longer distances in the swamp for hunting. Hunters also confirmed that catch per effort is also increasing. Some farmers are now venturing deeper into the hinterland, and are now exploring new grounds for turtle/tortoises hunting. IUCN [37] recent ratings suggest that $K$. homeana is vulnerable with population trend declining. Martin [33] reported that though bush meat is an economic activity in Nigeria, but it has environmental implications. Results of this study show that the number of entrants into the turtle/tortoises sales is increasing (Table 3). Turtle/tortoises have now become a primary occupation and income earner in these communities. Hence, the market is increasing.

About 8-10 eggs are found in the turtle/tortoises. The hunters report that the turtle/tortoises spawn twice yearly. The use of non-discriminating traps that catch both juveniles and females is a threat to the sustainability of turtle/tortoises exploitation. Habitat destruction for agriculture, industrialization and urbanization are major threats to the sustainability of turtle/tortoises in the Niger Delta.

\section{Conclusion}

The study presents the level of unsustainable exploitation of turtles and tortoises in the Niger Delta. Evidence has shown that this important freshwater habitats is under pressure due to anthropogenic influences such as urbanization, agriculture and oil and gas exploration the habitat is decreasing and becoming more fragmented [26], oil spills have also damaged turtle assemblages [23], bush burning have destroyed both the habitats and species [30], bush meat trade has impacted these species [24, 34]. Alacs et al [29] projected that the number and intensity of pressures will continue to rise which could be compounded by the climate change threat particularly flooding [25]. Many endemic species of turtles and tortoise have become 
threatened with extinction in Madagascar [30] and elsewhere [29]. Would this happen in Nigeria? Only time will tell.

\section{Acknowledgement}

The authors wish to thank Sylvester Izah for the editorial works.

\section{References}

[1] H. Uluocha, I. Okeke I. Implications of wetlands degradation for water resources management lessons from Nigeria. GeoJournal, 2004, pp. $151-154$.

[2] EA. Ajao, S. Anurigwo. Land-based sources of pollution in the Niger Delta, Nigeria. Ambio, 2002, vol. 5, pp. $442-45$.

[3] O Adekola, S. Whanda, F Ogwu. Assessment of policies and legislation that affect management of wetlands in Nigeria. Wetlands, 2012, pp. $665-677$.

[4] M. Spalding, F. Blasco, and C Field. World Mangrove Ecosystem Atlas. The international Society for Mangrove Ecosystem (IMSE), Japan. 1997.

[5] United Nations Development Programme (UNDP) (2012). Niger delta biodiversity project. UNDP Project document. Nigeria. 2012, pp. 171.

[6] N. Myers, R.A, Mittermeler, C.G Mittermeler, GAB. da Fonseca, J. Kents J. Biodiversity hotspots for conservation priorities. Nature, 2000, pp. $853-858$.

[7] DM, Olson, E. Dinerstein, ED. Wikramanayake, ND. Burgess, GVN. Powel, EC. Underwood, et al. Terrestrial ecoregions of the world: a new map of the earth. Bioscience 2001, pp. $933-938$.

[8] CB. Powell. Sites and species of conservation interest in the central axis of the Niger Delta (Yenagoa, Sagbama, Ekeremor and Southern Ijaw local government areas): A report of recommendations submitted to natural resource conservation council, NARESCON, Lagos. 1993.

[9] Powell CB. Discoveries and priorities for mammals in freshwater forests of the Niger Delta. Oryx 1997, vol. 2, pp. $83-85$.

[10] Pronatura International (2005). Report on Marine Turtle Survey within the Brass Island and adjoining Islands. A report submitted to Environmental Resources Managers Ltd, Lagos, Nigeria Raxworthy CJ, Nussbaum RA (2000). Extinction and extinction vulnerability of amphibians and reptiles in Madagascar. Amphibian and Reptile Conservation. 2005, vol. 1 pp. 15 - 23.

[11] A. Jerozolimski, M. Beatriz, N. Ribeiro, M. Martins. Are tortoise important seed dispersers in Amazonian forests? Oecologia 2009, pp. $517-528$.

[12] MJ. Dreslik, AR. Kuhns, CA. Phillips. Structure and composition of a southern Illinois freshwater turtle assemblage. Northeastern Naturalist. 2005, vol. 2 pp. $173-$ 186.

[13] RB. Bury. Population ecology of freshwater turtle. In: Harles M and Morlock H (eds.). Turtle: perspectives and
Research. John Wiley and Sons, New York, 1979, pp. $571-$ 602 .

[14] DM. DonnerWright, MA. Bozek, JR. Probst, EM. Anderson. Response of turtle assemblages to environmental gradient in the St. Croix River in Minnesota and Wisconsin, USA. Canadian Journal of Zoology 1999, pp. 989 - 1000.

[15] DL. Moll. Population sizes and foraging ecology in a tropical freshwater stream turtle community. Journal of Herpetology, 1990, pp.48 - 53.

[16] TJ. Vandewalle, JL. Christiansen. A relationship between river modification and species richness of freshwater turtles in Iowa. Journal of the Iowa Academy of Science.1996, pp. $1-8$.

[17] JM. Ayotamuno, EA. Gobo. Municipal solid waste management in Port Harcourt, Nigeria. Management of Environmental Quality: An International Journal, 2004, vol. 4, pp. $389-398$.

[18] SO. Abah and EI. Ohimain, E.I. Assessment of dumpsite rehabilitation potential using the integrated risk based approach: a case of Eneka, Nigeria. World Applied Sciences Journal, 2010, vol. 4, pp. 436442.

[19] DN. Ogbonna IKE, Ekweozor, FU, Igwe. Waste management: A tool for environmental protection in Nigeria. Ambio. 2002 vol. 1, pp. 55 - 57.

[20] EI. Ohimain, TOT. Imoobe, and MO. Benka-Coker. Impacts of dredging on zooplankton communities of Warri River, Niger Delta. African Journal of Environmental Pollution and Health. 2002, Vol. 1: 37-45.

[21] EI. Ohimain, and TOT, Imoobe. Algal bloom in a newly dredged canal in Warri, Niger Delta. The Nigerian Journal of Scientific Research. 2003, vol. 4, pp. 14-21.

[22] EI. Ohimain, W. Andriesse and MEF. van Mensvoort. Environmental Impacts of Abandoned Dredged Soils and Sediments: Available Options for their Handling, Restoration and Rehabilitation. Journal of Soils and Sediments, vol. 1, pp. 59-65.

[23] L. Luiselli and GC. Akani. An indirect assessment of the effects of oil pollution on the diversity and functioning of turtle communities in the Niger Delta, Nigeria. Animal Biodiversity and Conservation, 2003, vol. 1 pp. $57-65$.

[24] MK. Hamadina, D. Otobotekere, DI. Anyanwu. Impact assessment and biodiversity considerations in Nigeria. A case study of Niger Delta University campus project on wildlife in Nun River forest reserve. Management of Environmental Quality: An International Journal, 2007, vol. 2 pp. $179-197$.

[25] EI, Ohimain, SC. Izah and D. Otobotekere. Selective Impacts of the 2012 Water Flood on the Vegetation and Wildlife of Wilberforce Island, Nigeria. International Journal of Environmental Monitoring and Analysis. 2014, In Press.

[26] AO. Onojeghuo and A. Blackburn. Forest transition in an ecologically important region: patterns and causes for landscape dynamics in the Niger Delta. Ecological Indicators, 2011, pp. $1437-1446$.

[27] EO. Wilson . A global biodiversity map. Science. 2000, pp. 289- 2279. 
[28] GA. Krupnick and WJ. Kress. Hotspots and ecoregions: a test of conservation priorities using taxanomic data. Biodiversity and Conservation, 2003, pp. $2237-2253$.

[29] EA. Alacs, FJ. Janzen, Scribner. Genetics issues in freshwater Turtle and Tortoise conservation. Turtle conservation genetics working group. Chelonian Research Monographs 2007, vol. IV. pp.107- 123.

[30] C. Raxworthy and R. Nussbaum, R. Extinction and extinction vulnerability of amphibians and reptiles in Madagascar. Amphibian and Reptile Conservation, 2000, vol. II, pp.15-23.

[31] D. Moll and EO. Moll. The ecology, exploitation and conservation of river turtles. 2004, Oxford University press, Oxford.

[32] PP. Van Dijk, BL. Stuart, AGJ. Rhodin. Asian Turtle trade: proceedings of a workshop on conservation and trade of freshwater turtles and tortoises in Asia. Chelonian Research Monographs, 2000, vol. II, pp. 164.

[33] GHG. Martin. Bushmeat in Nigeria as a national resource with environmental implications. Environmental
Conservation, 1983, pp. $125-131$.

[34] BA. Ola-Adams. Strategies for conservation and utilization of forest genetic resources in Nigeria. Nigerian Journal of Forestry, 1981, pp. $32-40$.

[35] ED. Politano. Studio dell'ecosistema di un'area del Delta del fiume Niger, Nigeria, conriferimento allo sfruttamento industrial petrolifero. 1985, ENI S.P.A, Rome.

[36] CH. Ernst and RW. Barbour. Turtles of the World. 1986, Smithsonian Institution Press. Washington, D.C. and London.

[37] IUCN. IUCN Red List of Threatened Species. Version 2012. $<$ www.iucnredlist.org $>$. Downloaded on 29 October 2012.

[38] SC. Sterrett, SL, Smith, LL. Schweitzer, SH. Maerz. An assessment of two methods for sampling river turtle assemblages. Herpetological Conservation and Biology 2010 , pp. $490-497$.

[39] DL. Crosswhite, SF. Fox and RE. Thill RE. Comparison of methods for monitoring reptiles and amphibians in upland forests of the Ouachita Mountains. Proc. Okla. Acad. Sci. 1999, pp. $45-50$. 